Article

\title{
Increased Stability of Oligopeptidases Immobilized on Gold Nanoparticles
}

\author{
Marcelo Yudi Icimoto ${ }^{1, *}$, Adrianne Marlise Mendes Brito ${ }^{1,2}$, Marcos Paulo Cyrillo Ramos ${ }^{1}$, \\ Vitor Oliveira ${ }^{1}$ (D) and Iseli Lourenço Nantes-Cardoso ${ }^{2, *}$ (D) \\ 1 Departamento de Biofísica, Universidade Federal de São Paulo, São Paulo CEP 04024-002, Brazil; \\ adriannemmb@gmail.com (A.M.M.B.); mcyrilloramos@gmail.com (M.P.C.R.); \\ vitor.oliveira@unifesp.br (V.O.) \\ 2 Centro de Ciências Naturais e Humanas, Universidade Federal do ABC, Santo André CEP 09210-580, Brazil \\ * Correspondence: icimoto@unifesp.br (M.Y.I.); ilnantes@ufabc.edu.br (I.L.N.-C.)
}

Received: 21 October 2019; Accepted: 16 December 2019; Published: 4 January 2020

check for updates

\begin{abstract}
The metallopeptidases thimet oligopeptidase (THOP, EC 3.4.24.25) and neurolysin (NEL, EC 3.4.24.26) are enzymes that belong to the zinc endopeptidase M13 family. Numerous studies suggest that these peptidases participate in the processing of bioactive peptides such as angiotensins and bradykinin. Efforts have been conducted to develop biotechnological tools to make possible the use of both proteases to regulate blood pressure in mice, mainly limited by the low plasmatic stability of the enzymes. In the present study, it was investigated the use of nanotechnology as an efficient strategy for to circumvent the low stability of the proteases. Recombinant THOP and NEL were immobilized in gold nanoparticles (GNPs) synthesized in situ using HEPES and the enzymes as reducing and stabilizing agents. The formation of rTHOP-GNP and rNEL-GNP was characterized by the surface plasmon resonance band, zeta potential and atomic force microscopy. The gain of structural stability and activity of rTHOP and rNEL immobilized on GNPs was demonstrated by assays using fluorogenic substrates. The enzymes were also efficiently immobilized on GNPs fabricated with sodium borohydride. The efficient immobilization of the oligopeptidases in gold nanoparticles with gain of stability may facilitate the use of the enzymes in therapies related to pressure regulation and stroke, and as a tool for studying the physiological and pathological roles of both proteases.
\end{abstract}

Keywords: THOP; NEL; gold nanoparticles; oligopeptidases

\section{Introduction}

Gold nanoparticles (GNPs) are attractive for biological applications because of the stability, biocompatibility, facile functionalization and compatibility with organic molecules containing thiol groups [1]. GNPs encompass both the intrinsic properties of nanoscale, surface effects and quantum confinement and the capacity to undergo surface functionalization that can increase stability and provide specific targeting [2]. Surface functionalization of gold nanoparticles has opened new frontiers for the delivery of drugs such as anticancer and antimicrobial drugs as well as functional studies of biomolecules such as enzymes and antibodies [3-6]. GNPs can also be synthesized by one-pot, rapid processes, including the in-situ synthesis using the organic functionalizing agent as the reducing compound to convert gold ions $\left(\mathrm{Au}^{3+}\right)$ to the metallic form [7-9]. A diversity of biomolecules and their mimetics has been used for in-situ synthesis of GNPs, but the use of proteins is particularly attractive because these biomolecules act as a template and reducing agents for GNP fabrication [10-13].

Several enzymes have the potential for therapeutic applications that can be limited by their stability, and this is the case of the enzymes thimet oligopeptidase (THOP; EC 3.4.24.15) and neurolysin (NEL; EC 3.4.24.16). THOP and NEL promise as hypotensive therapeutics despite their low structural 
and functional stability. THOP and NEL are members of the thermolysin-like mammalian zinc endopeptidase family [14], which is maximally active at neutral $\mathrm{pH}$ and is among the most studied groups of peptidases responsible for hydrolytic processing of bioactive peptides in both intra and extracellular environment [15]. These enzymes are found in animals and plants, showing distinctive functions [16]. Biochemical and pharmacological features have been well characterized in vivo and in vitro $[14,15,17,18]$ with well-known endogenous substrates such as hemopressin, bradykinin, angiotensins I and II, neurotensin, substance P, dynorphin A (1-8), somatostatin and A $\beta$ peptide (amyloid peptide). The processing of these substrates is related to the regulation of a myriad of physiological processes [19]. Despite the capacity to process a variety of endogenous substrates, the functional significance of THOP and NEL in pathophysiological conditions is poorly understood, linking their function to neurotensin-dependent nociception, bradykinin-mediated hypotension, microvascular permeability and hyperalgesia $[20,21]$.

Neurotensin (NT) is a tridecapeptide that exerts a broad range of cardiovascular and endocrine effects when administered intravenously, including hypotension, analgesia and hypothermia [22-24]. The roles of THOP and NEL in the inactivation of neurotensin in vitro were determined by several studies. NEL was the only peptidase ubiquitously contributing to its inactivation, being present in all tissue and established cell lineages where NT receptors are located $[23,25]$. THOP, on the other hand, cleaves NT at the Arg-Arg bond and reduces NT in rat brain synaptosomes [26]. The use of specific inhibitors also increases the evidence for the involvement of both enzymes in the physiological degradation of NT, as the dipeptide Pro-Ile [27] and phosphinic peptides [28].

In addition to possible functions within the brain, THOP may also play a role in the periphery. The potent vasodilatory peptide bradykinin (BK) is a powerful influence in stimulating extravascular smooth muscle contraction, inducing hypotension, dilating blood vessels and increasing vascular permeability $[29,30]$. THOP has been shown to efficiently degrade BK in vitro at the Phe-Ser bond [31,32]. The use of the THOP specific inhibitor JA2 was shown to potentiate BK-induced hypotension, without affecting the hypertensive effects of angiotensins I and II, strongly suggesting its role in blood pressure control [22]. THOP also significantly affects BK in the kidney, having a role in blood flow, glomerular filtration rate, urinary sodium and potassium excretion and urine volume [33-36]. Furthermore, THOP also converts angiotensin I in vitro to the biologically active peptide angiotensin 1-7 [37] synergizing with the effects of bradykinin in vascular smooth muscle cells culture $[38,39]$ and in rat hindlimb perfusate ex vivo [40]. Thus, THOP may participate in cardiovascular homeostasis via the activation (angiotensin 1-7) and inactivation (bradykinin) of vasodilatory peptides.

Therefore it is necessary, both in vivo and in cell culture approaches, to perform functional studies of these enzymes when administered as exogenous agents [41,42]. The lack of cytotoxicity, low blood stability, systemic bioavailability and pharmacokinetics of intraperitoneally administered recombinant neurolysin, and its effects on critical physiological parameters in mice have already been demonstrated [43]. These studies suggest that NEL can serve as a research tool and could contribute to a better comprehension of the functional significance of this peptidase in diseases $[44,45]$. The potential for the therapeutic application of THOP and NEL allied to the necessity of prolonged structural stability motivated the present study to develop THOP, and NEL capped GNPs. The results demonstrate a significant gain of stability necessary for therapeutic applications. In fact, the redox balance is closed related to the mitochondrial permeability transition. Furthermore, it was demonstrated that THOP activity can be regulated by peroxide concentrations in cells that in turn are modulated by the cellular thiol oxidation status [46-48].

\section{Results and Discussion}

\subsection{Enzyme Expression and Purification}

The optimum growth of Escherichia coli BL21-DE3 containing the pET28a (+) constructs for expression of both recombinant thimet oligopeptidase and neurolysin (rTHOP and rNEL) was achieved 
using LB broth medium at $20^{\circ} \mathrm{C}, 180 \mathrm{rpm}$, induced by $1 \mathrm{mM}$ IPTG for $24 \mathrm{~h}$. Active proteases were isolated from lysed bacteria culture using affinity-based HisTrap FF column (GE) eluted in a $50 \mathrm{mM}$ Tris-buffer $100 \mathrm{mM} \mathrm{NaCl} \mathrm{pH} 7.4$ and $250 \mathrm{mM}$ imidazole (rTHOP) or $200 \mathrm{mM}$ imidazole (rNEL) resulting in protein purity greater than $90 \%$ (Figure 1a). Purified proteases were observed as single bands on SDS-PAGE with apparent molecular weights as $78 \mathrm{kDa}$ for THOP and NEL. The structural profile was confirmed using the circular dichroism (CD; Figure 1b), consistent with previous literature data [49]. The far-UV CD spectra of rTHOP and rNEL show that the recombinant enzymes are folded with high $\alpha$-helix content and consequently suitable for activity-based assays that are described herein.

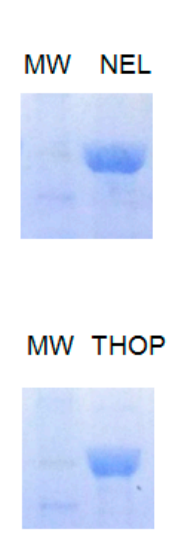

(a)

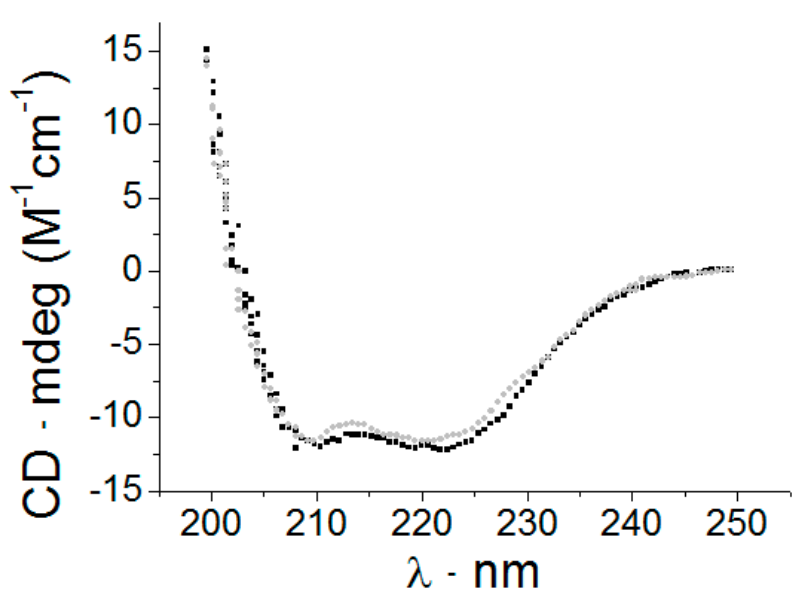

(b)

Figure 1. Purification of recombinant oligopeptidases THOP (EC 3.4.24.15) and NEL (EC 3.4.24.16). (a) Twelve percent SDS-Page of purified recombinant THOP and NEL followed by Coomassie Blue staining, indicating the purification homogeneity. (b) Circular dichroism profile of rTHOP and rNEL, demonstrating a proper fold after purification. All samples were prepared, and the spectra obtained, as described in Materials and Methods.

\subsection{Enzyme Thermostability}

The thermostability of THOP and NEL were assessed by previous incubation in defined temperature in buffered aqueous solutions (not immobilized) and immobilized in a $1 \%$ agarose matrix. Activity assays were performed by measurement at $37{ }^{\circ} \mathrm{C}$ on the fluorogenic substrate Abz-GFSPFRQ-EDDnp after each step of enzyme challenging to a temperature ramp of $5{ }^{\circ} \mathrm{C}$ per 20 min (Figure 2). Figure 2a shows that in solution, rTHOP and rNEL have the turning point (half-activity) of temperature-induced denaturation and loss of activity at $60^{\circ} \mathrm{C}$. When immobilized in a $1 \%$ agarose matrix, the half-activities of THOP and NEL increased to $75^{\circ} \mathrm{C}$ (Figure 2b). A plausible explanation for the gain of thermal stability in an agarose matrix, at least in the case of THOP, is a probable impairment of inactivating enzyme oligomerization that is observed after a few hours of incubation in solution. Considering that oligomerization involves the formation of intermolecular disulfide [50,51], the reducing agent DTT was also used as control. It also used the THOP cysteine mutant $6 \mathrm{M}$, where all six surface-exposed cysteine residues were mutated to serine (Figure 2c). DTT preincubation and THOP mutations promoted a small increase of rTHOP and rNEL thermal resistance. This result can be rationalized considering that the oligomerization promoted by heating is preceded by unfolding, which exposes internal cysteine residues and results in an intermolecular reaction. The better thermal resistance obtained for the peptidases in the agarose matrix demonstrates the importance of immobilization for the gain of stability. The aspects of THOP and NEL stability regulation by reducing agents are already well discussed in the literature, and they were the result of a combined effect of mixed forms of inactive oligomerized enzymes and oxidation as post-translational modification $[47,50]$. 


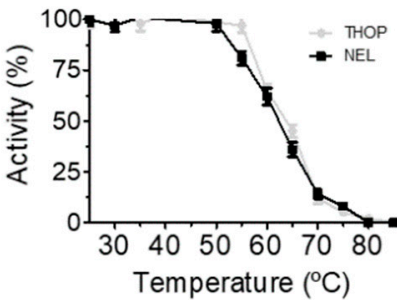

(a)

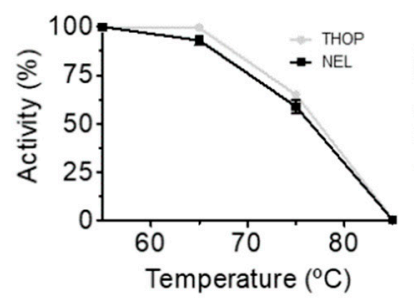

(b)

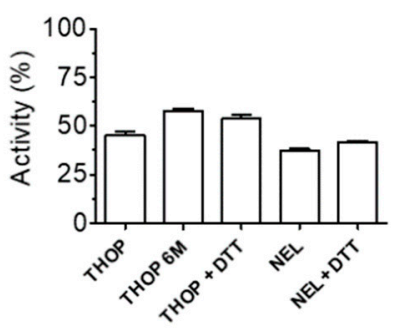

(c)

Figure 2. Thermostability of in solution and agarose-immobilized rTHOP and rNEL. Recombinant enzymes were preincubated for $20 \mathrm{~min}$ at each temperature in activity buffer (a) in solution or (b) immobilized in 1\% agarose, indicating the positive effect of agarose in enzyme stability. The effect of the reducing agent DTT and THOP cysteine mutant $(6 \mathrm{M})$ was also observed in solution (without immobilization) at the fixed temperature of $65^{\circ} \mathrm{C}(\mathrm{c})$, suggesting that the increase in stability observable in (b) is mainly due to immobilization and not to enzyme oligomerization or other protein-protein interactions. Activities of both THOP and NEL were accessed by using the fluorogenic substrate Abz-GFSPFRQ-EDDnp $(5 \mu \mathrm{M})$ in Tris- $\mathrm{NaCl}$ buffer at $37^{\circ} \mathrm{C}$ in a spectrofluorimeter Hitachi F7000.

\subsection{In-Situ Synthesis of rTHOP-GNPs and rNEL-GNPS}

The temperature for the synthesis of GNPs in situ using rTHOP and rNEL as reducing agents was established at $40{ }^{\circ} \mathrm{C}$ in which the enzymes had $100 \%$ of activity. The preservation of enzyme activity is associated with the native folded structure of the enzymes that assures that the proteins can also act as a template for GNP growing. rTHOP- and rNEL-assisted synthesis of GNPs was performed at different enzyme concentrations (Figures 3 and 4, respectively). Considering that both THOP and NEL have different exposed cysteine content, different protein concentration implicates in variable reductive power of the system, which may affect the physicochemical properties of the nanoparticles generated. We considered the reductive capacity of the system as the molar concentration of exposed cysteine residues and protein concentration during protein-GNP synthesis. The spectra of rTHOPand rNEL-GNPs, synthesized at $40{ }^{\circ} \mathrm{C}$, using protein concentrations at 2, 8, 40 and $200 \mathrm{nM}$ are shown in Figure 3 (rTHOP-GNP) and Figure 4 (rNEL-GNP), respectively as well as appropriated controls. In order to guarantee any unbounded enzymes in protein-GNP preparations, the synthesized GNPs were three times washed by ultracentrifugation $\left(50.000 \mathrm{~g}, 5 \mathrm{~min}\right.$ at $\left.4{ }^{\circ} \mathrm{C}\right)$ followed by resuspension. GNP synthesis was successful in all tested protein concentrations, evidenced by the appearance of surface plasmon resonance (SPR) spectral bands peaking around $535 \mathrm{~nm}$ in the UV-vis spectra. The spectra of THOP1 $(200 \mathrm{nM})$ and THOP2 $(40 \mathrm{nM})$ generate broader SPR bands, possibly indicating polydispersed particles. The same observation was suggested for NEL1 $(200 \mathrm{nM})$. However, the relatively low-intensity rNEL-GNP spectrum obtained from the synthesis using $200 \mathrm{nmol} . \mathrm{L}^{-1}$ of protein reflects colloidal instability, as observable in the stability assay (Figure 5). 

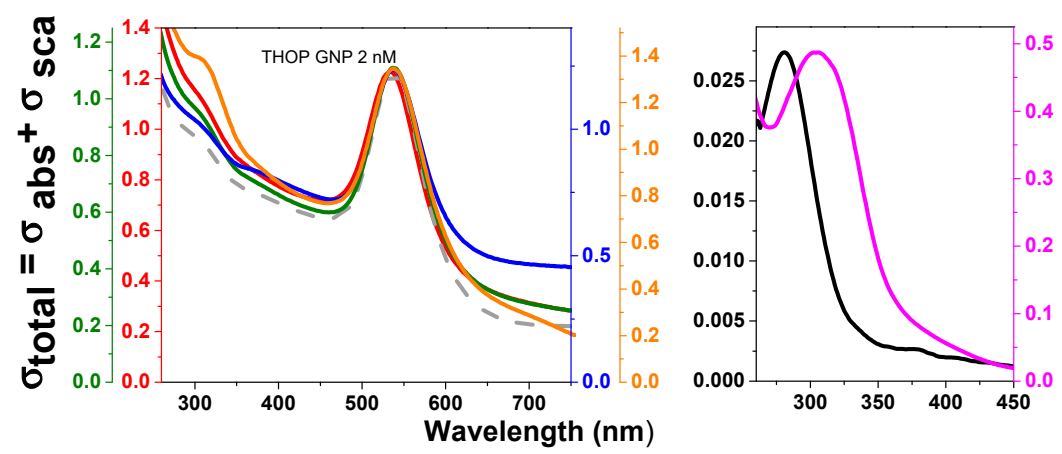

Figure 3. UV-vis spectra of rTHOP-gold nanoparticles (GNPs) synthesized with different THOP concentrations. Spectra of THOP-GNPs were obtained from synthesis using 200, 40, 8 and 2 nM of recombinant THOP. These values correspond to 1200, 240, 48 and $12 \mathrm{nM}$ of exposed sulfhydryls. Red: THOP-GNP 2 nM. Green: THOP-GNP 8 nM. Blue: THOP-GNP 40 nM. Orange: THOP-GNP, 200 nM. Gray dashed line: GNP-HEPES (without protein). Black: THOP protein. Pink: reaction without HEPES. The wavelength of $300 \mathrm{~nm}$ corresponds mainly to Au-protein complexes absorption and $535 \mathrm{~nm}$ to the surface plasmonic resonance (SPR) band of the nanoparticle. The samples were prepared, and the spectra obtained as described in Materials and Methods.

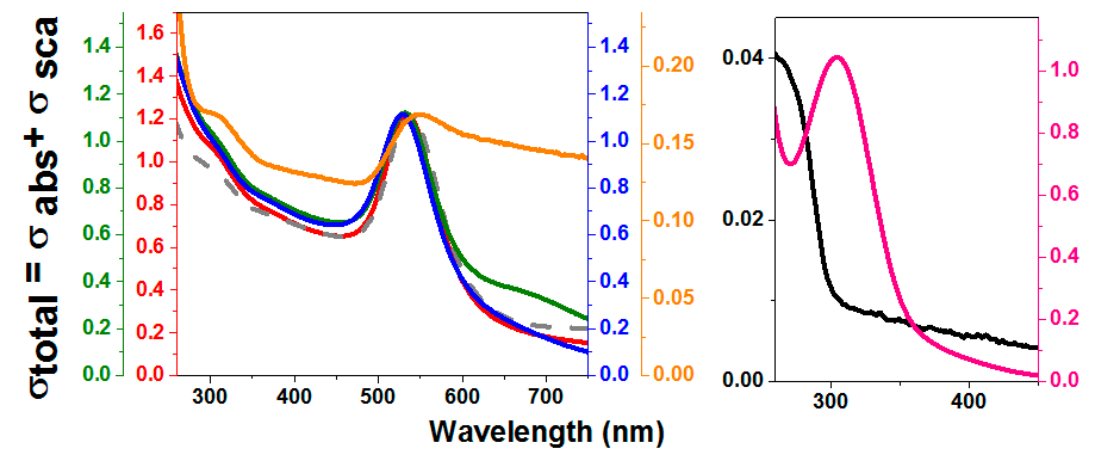

Figure 4. UV-vis spectra of rNEL-GNP synthesized with different NEL concentrations. Spectra of NEL-GNPs were obtained from the synthesis using NEL at 200, 40, 8 and $2 \mathrm{nM}$, corresponding to 1000, 200, 40 and $10 \mathrm{nM}$ of exposed sulfhydryls. Red: NEL-GNP ( $2 \mathrm{nM})$. Green: NEL-GNP (8 nM). Blue: NEL-GNP (40 nM). Orange: NEL-GNP (200 nM). Gray dashed line: GNP-HEPES without Protein. Black: NEL protein. Pink: reaction without HEPES. The wavelength of $300 \mathrm{~nm}$ corresponds mainly to Au-protein complex absorption and $535 \mathrm{~nm}$ to the plasmonic band of the nanoparticle. Spectra were obtained in a spectrophotometer Evolution 200 (Thermo Scientific) at room temperature.

The position of SPR bands of GNPs between 525 and $535 \mathrm{~nm}$ that was obtained for all THOPand NEL-GNPs synthesized it was possible an estimative of the GNP diameter between 20 and $60 \mathrm{~nm}$ based in literature data [52]. The stoichiometry protein/nanoparticles can also be calculated. Considering the mean diameter of $40 \mathrm{~nm}$, in atomic spherical metal clusters [53,54], the concentration of protein-GNPs obtained in our synthesis is $1 \mathrm{nM}$, resulting in a THOP/NEL:GNP ratio of 2:1 rTHOP and rNEL GNPs synthesized in the presence of $2 \mathrm{nmol} . \mathrm{L}^{-1}$ of the proteins. The spherical shape of rTHOP and rNEL GNPs with a mean diameter of $40 \mathrm{~nm}$ was corroborated by atomic force microscopy (AFM) measurements (Figure 5a,b). Figure 5a depicts a 2D representation of rTHOP-GNP, while Figure 5a, inset, depicts a 3D representation of the same bio-functionalized nanoparticle, indicating monodispersed GNPs and suggesting spherical shapes of the particles. Similarly, Figure 5b, inset, represent rNEL-GNP in 2D and 3D perspectives, respectively. 


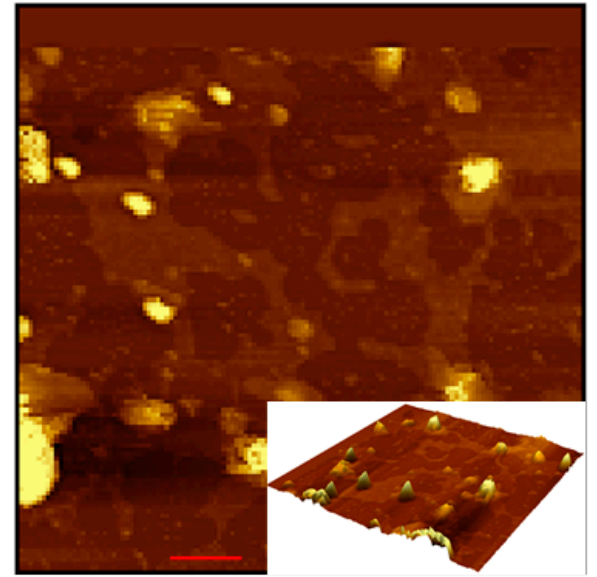

(a)

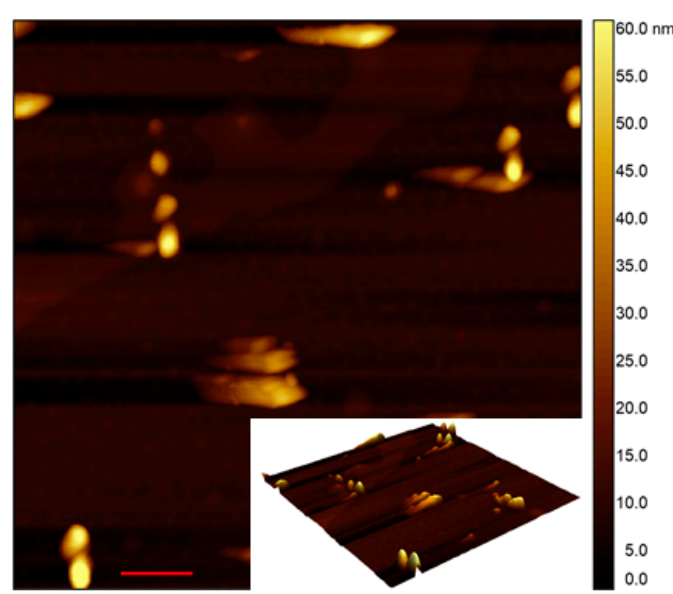

(b)

Figure 5. Atomic force microscopy of rTHOP-GNP and rNEL-GNP. Atomic force microscopy (AFM) measurement of (a) rTHOP-GNP and (b) rNEL-GNP 2D images are observable (red scale bar = $200 \mathrm{~nm}$ ) as the central figure and 3D rendering of as insets of $(\mathbf{a}, \mathbf{b})$ for rTHOP-GNP and rNEL-GNP, respectively.

Despite the significant differences observed in the UV region, the SPR bands of GNP synthesized in the absence and presence of the enzymes are very similar as well as the zeta potential values that were determined for GNPs synthesized with HEPES and HEPES assisted by 2 nmol.L ${ }^{-1}$ of THOP and NEL $(-25.4+/-5.48,-25.9+/-4.97$ and $-22.2+/-5.18 \mathrm{~V}$, respectively). Therefore, some experiments were carried out to check the binding capacity of THOP and NEL on the surface of GNPs. Bare GNPs were synthesized using sodium borohydride, and the changes in the UV-vis spectrum and zeta potential values were determined after the addition of 2 nmol. $\mathrm{L}^{-1}$ of the enzymes at $\mathrm{pH} 3.5$, which is below their pI (isoelectric point) values. Bare gold nanoparticles presented spectral changes consistent with nanoparticle aggregation by changing the $\mathrm{pH}$ from 6.0 to 3.5 that is accompanied by change of the zeta potential from $46.9+/-2.45$ to $23.5+/-0.72 \mathrm{mV}$ (Table S1 in Supplemental Material). The addition of THOP for a final concentration of $2 \mathrm{nmol} . \mathrm{L}^{-1}$ promoted significant spectral changes that are compatible with nanoparticle disaggregation (Figure S1 in Supplemental Material). The enzyme immobilization on bare GNPs was also corroborated by zeta potential measurements of bare gold nanoparticles in the same conditions used for the UV-visible spectral measurements at $\mathrm{pH}$ 3.5. The addition of THOP for a final concentration of $2 \mathrm{nmol} . \mathrm{L}^{-1}$ changed the zeta potential of bare GNPs at $\mathrm{pH} 3.5$ from $-23.5+/-$ $0.72 \mathrm{mV}$ to $34.2+/-1.85 \mathrm{mV}$ (Table S1 in Supplemental Material). However, bare gold nanoparticles synthesized with sodium borohydride had a diameter of $5.7+/-1.7 \mathrm{~nm}$ (Figure S2 in Supplemental Material) while the gold nanoparticles fabricated using HEPES were ca. six-fold larger. Therefore, considering the low protein concentration that was compatible with a mean of two proteins/gold nanoparticles (Figure 6), it was expected that the protein adsorption on gold nanoparticles produced using HEPES is unable to promote significant changes in zeta values because of the low superficial area of GNPs covered by the enzymes. 


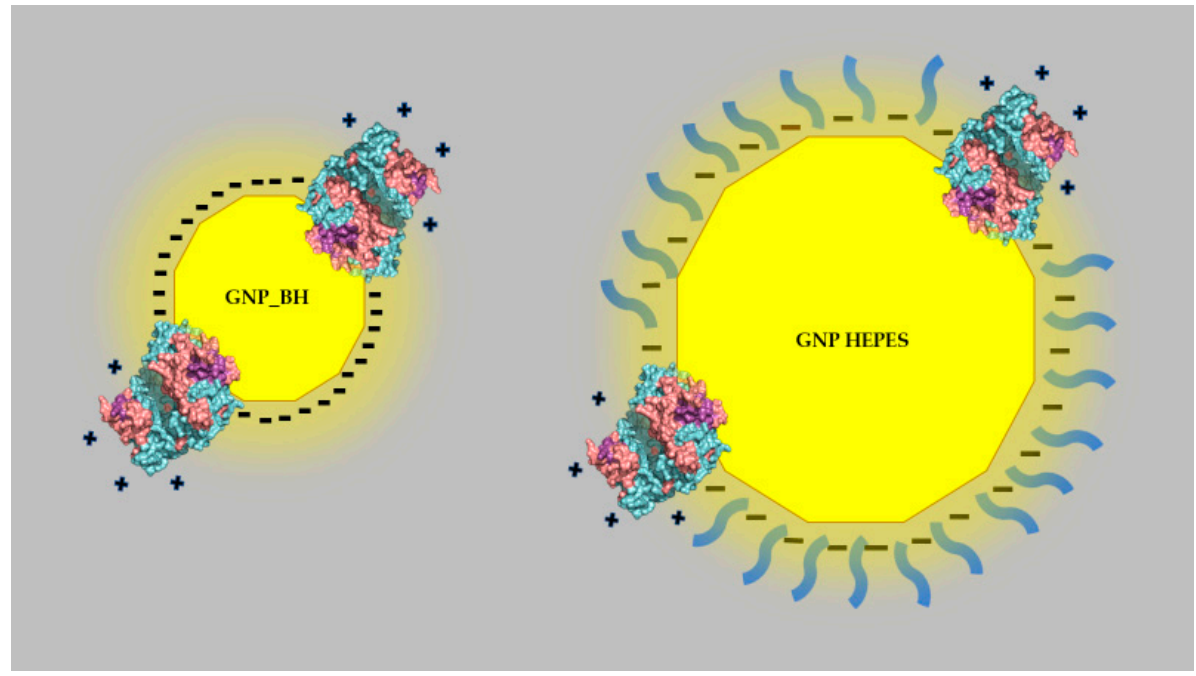

Figure 6. Cartoon representative of a putative effect of nanoparticle size on the zeta potential promoted by the adsorption of the proteases.

The immobilization of THOP and NEL on the GNPs fabricated with HEPES and assisted by the enzymes was also corroborated by differences in the kinetics of synthesis, colloidal stability, and the presence of proteolytic activity in the GNPs produced with HEPES and assisted by the enzymes.

\subsection{Kinetics of rTHOP-GNP and rNEL-GNP Formation}

Considering the interest in the use of THOP- and NEL-GNPs as catalysts, it is essential to have effective enzyme immobilization and activity in the same conditions in which free enzymes are active. Therefore, the kinetics of HEPES-GNP synthesis assisted by the enzymes were compared with the kinetics of GNPs synthesized with HEPES alone. Figure 7a shows the kinetic of GNP synthesis by using $30 \mathrm{mM}$ HEPES as a reducing and stabilizing agent in the absence of THOP and NEL that is compared with the respective synthesis kinetics of GNP formation assisted by 2 nmol.L ${ }^{-1}$ THOP and NEL (Figure $7 \mathrm{~b}, \mathrm{c}$ respectively). In all the conditions used, it was observed that the kinetics of GNP synthesis in the presence of HEPES had three essential observable steps: progressive spectral changes in the UV region that corresponded to the occurrence of gold ion reduction and formation of nanoclusters (step 1), SPR band formation (step 2) and the progressive increase of a broad band at the spectral range of 700-800 $\mathrm{nm}$. Considering the three steps of synthesis that involves changes in the UV region, followed successively by increasing of SPR bands and a band around $750 \mathrm{~nm}$, Figure $7 \mathrm{a}-\mathrm{c}$ show the kinetics of synthesis monitored at $310 \mathrm{~nm}, 532-535 \mathrm{~nm}$ and around $750 \mathrm{~nm}$ and the insets with the corresponding spectra obtained in the course of the synthesis. The kinetics of GNP formation in the processes assisted by the enzymes was significantly different of that promoted by HEPES alone, especially at the steps of involving changes in the visible region. Considering the high concentration of HEPES relative to the enzymes, it was expected that the buffering agent is the principal agent for gold ion reduction and nanoclusters nucleation in step 1. After the formation of nanoclusters, the association with the enzymes at some nanoclusters facets drives the nanoparticles growing and consequently the kinetics of SPR and the 700-800 $\mathrm{nm}$ band increasing. It is important to note that for GNPs synthesized in the absence of enzymes the band in the red region of the spectrum that appeared in the third step peaks at $715 \mathrm{~nm}$ whereas in the synthesis assisted by the enzymes the peak was found at $765 \mathrm{~nm}$. The nature of this band remains to be determined but it is suggestive of the formation of elongated nanostructures or aggregates. 
(a)

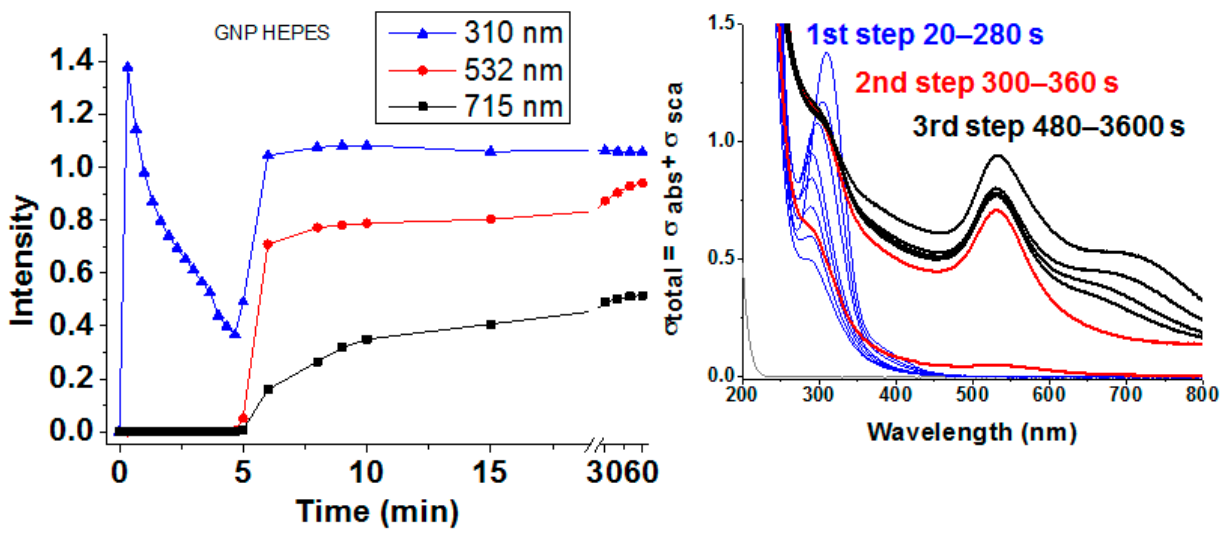

(b)
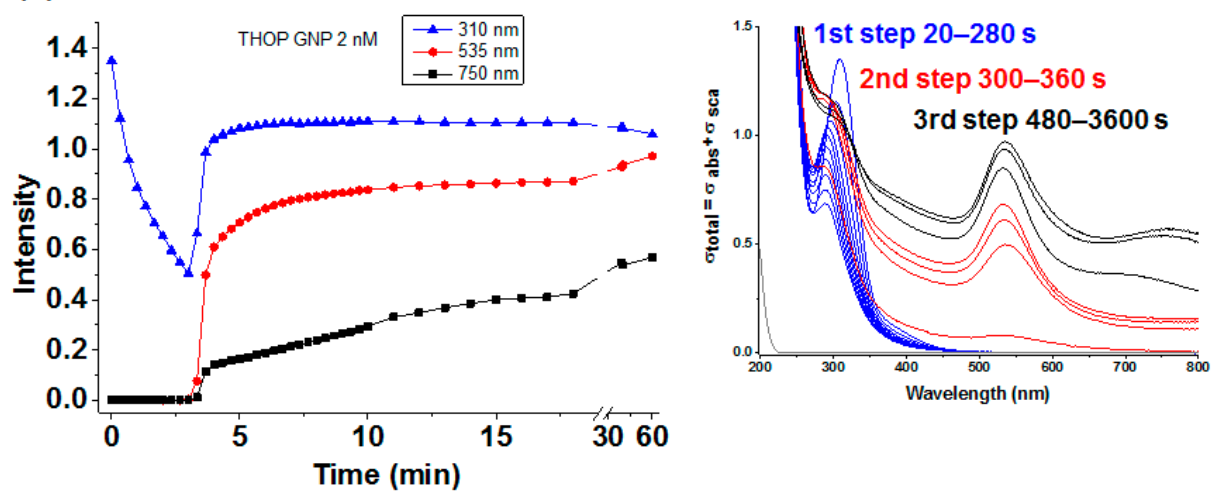

(c)
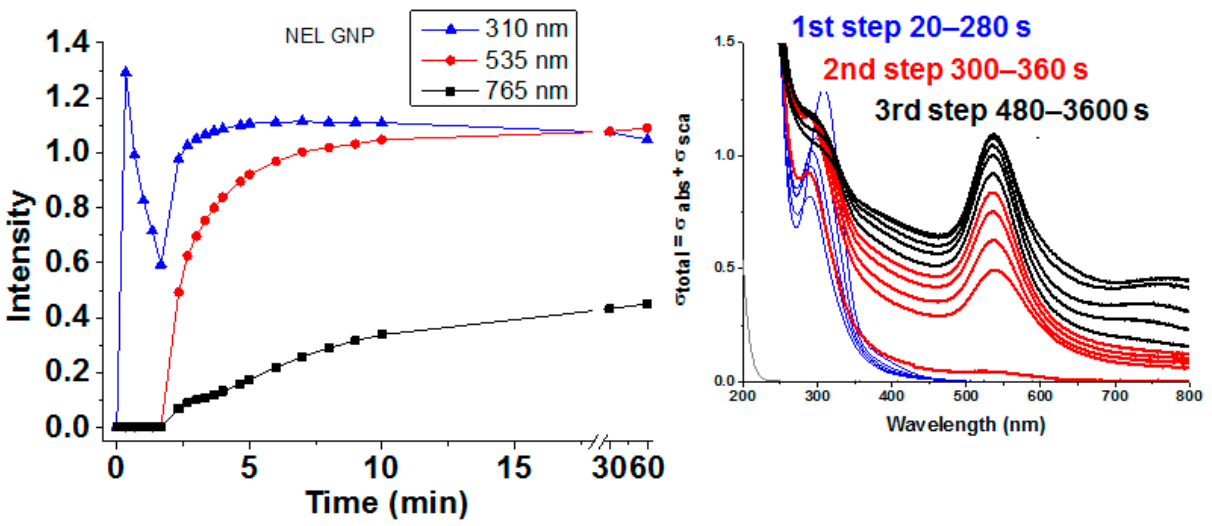

Figure 7. Kinetics of GNP synthesis with HEPES in the absence and presence of enzymes. (a), (b) and (c) represent the kinetics of the three steps of the GNP synthesis using HEPES alone, and HEPES assisted by THOP and NEL, respectively. In each spectra the blue lines represent kinetic and corresponding spectra (inset) of $\mathrm{HAuCl}_{4}$ immediately after addition to solution (time zero) and the formation of the complex HEPES/gold ions and protein with subsequent reduction of $\mathrm{Au}^{3+}$ to the atomic form before the appearance of Surface Plasmon Resonance (SPR, first-step), red lines represents the represent kinetic and corresponding spectra (inset) obtained during the GNP formation evidenced by SPR peaking at $535 \mathrm{~nm}$ (second-step) and the black lines represent kinetic and corresponding spectra (inset) GNP aggregation and modification evidenced by a progressive increase of an additional band at $750 \mathrm{~nm}$ (third-step). All samples were prepared, and the spectra carried out as described in Materials and Methods. The appearance of SRP bands during GNP synthesis assisted by rTHOP and rNEL was earlier than in the synthesis by HEPES in the absence of enzymes but the absorbance increasing is slower. The kinetics difference observed in the presence of the enzymes is consistent with these proteins participating in the GNP growing step as reducing agent and template. 
The association of GNPs with the enzymes THOP and NEL was also crucial for the colloidal stability of the nanoparticles as described herein.

\subsection{Colloidal Stability of rTHOP-GNP and rNEL-GNP}

The colloidal stability of GNPs associated with enzymes is essential for catalytic and therapeutic applications. Therefore, rTHOP- and rNEL-GNP suspensions were analyzed by naked eyes for 10 days of resting at room temperature (Figure 8, left panel). All the purple-red suspensions remained stable on the day of synthesis. Gradually, colloidal suspensions produced with 40 and $8 \mathrm{nmol} . \mathrm{L}^{-1}$ of rTHOP and 200 and $8 \mathrm{nmol} . \mathrm{L}^{-1}$ of rNEL lost colloidal stability and resulted in the formation of visually detectable precipitates after 10 days of resting. In contrast, GNPs suspensions produced with 2 nmol. $\mathrm{L}^{-1}$ of rTHOP, as well as with 40 and $8 \mathrm{nmol} . \mathrm{L}^{-1}$ of rNEL, showed exceptional colloidal stability. The protein-GNPs suspension with colloidal stability after 10 days (produced with THOP 2 nmol.L $\mathrm{L}^{-1}$ and NEL 2 nmol.L $\mathrm{L}^{-1}$ ) are also evidenced by UV-vis spectra (Figure 8, right panel) and were elected for the determination of the synthesis kinetics that are depicted in the next section.

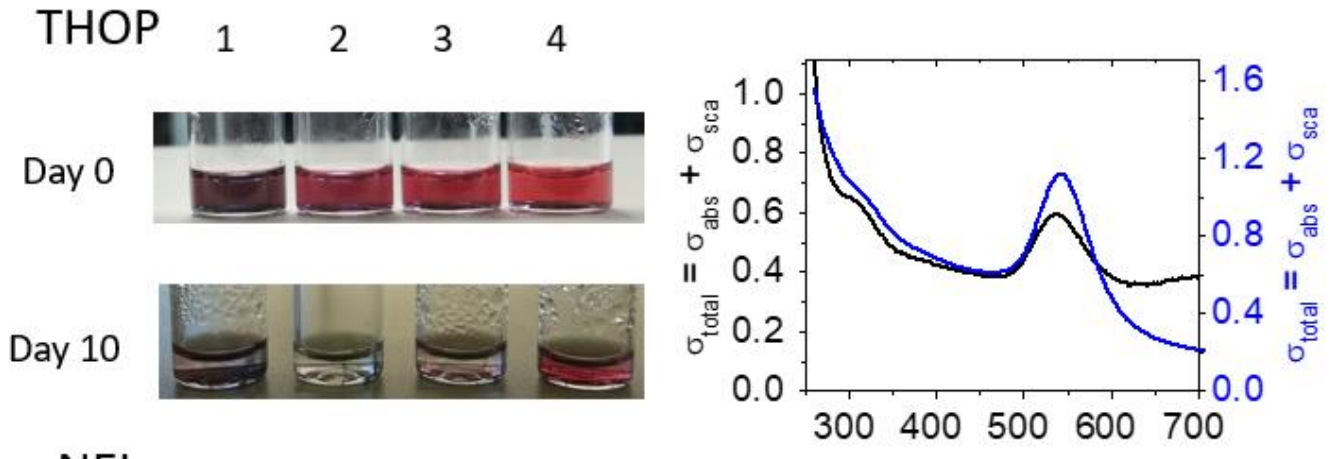

NEL

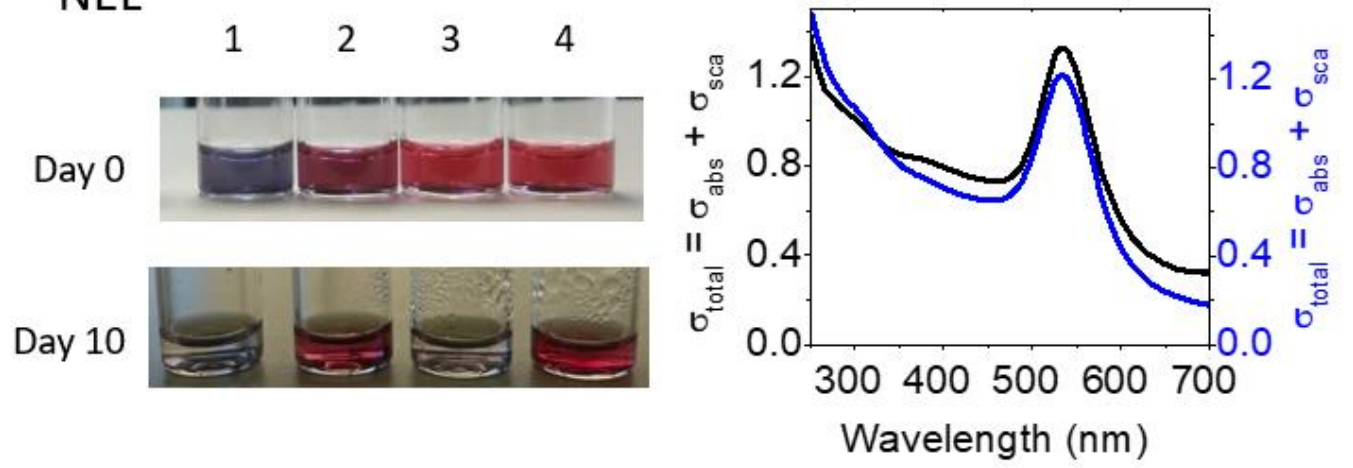

Figure 8. Colloidal stability of THOP-GNP and NEL-GNP. The stability of GNPs produced by HEPES assisted by proteases at the four tested concentrations was followed for 10 days. The left panel depicts the visual aspects of fresh synthesized (day 0) and protein-GNP after 10 days. The UV-vis spectra of rTHOP $\left(2 \mathrm{nmol} . \mathrm{L}^{-1}\right)$ and rNEL $\left(2 \mathrm{nmol} . \mathrm{L}^{-1}\right)$ nanoparticles after 10 days (black lines) indicate the colloidal stability of both rTHOP-GNP and rNEL-GNP preparations compared to freshly synthesized protein-GNPs (day 0, blue line). The lower stability of rTHOP-GNP produced with 200, 40 and $8 \mathrm{n} \mathrm{nmol.L^{-1 } \text { , and rNEL-GNP produced with rNEL at } 2 0 0 \mathrm { nmol } . \mathrm { L } ^ { - 1 } \text { and } 8 \mathrm { nmol.L }} \mathrm{L}^{-1}$ leading to nanoparticle precipitation is noteworthy.

It is interesting to relate the differential colloidal stability of THOP-GNP and NEL-GNP when we consider their structures. Figure 9 shows the Protein Data Bank structure of THOP (1S4B) and NEL (1I1I) in which is evident a highly similar structure of these enzymes. However, it is well-known that free THOP and NEL have different stability. Contrary to NEL, THOP loses activity due to interchain disulfide bonds oligomerization or post-translational modifications of oxidative nature in its surface-exposed cysteine residues. These changes have been associated with the reactivity of three acidic cysteine residues (low pKa of lateral chain thiol group) that are in proximity to the basic amino 
acid residues, arginine, and lysine. In NEL structure, however, there is only a solvent-exposed acidic cysteine residue Cys247 that, similarly to Cys246 of THOP, is sided by arginine and lysine residues. The difference of colloidal stability between THOP- and NEL-capped gold nanoparticles is one more evidence of protein immobilization.

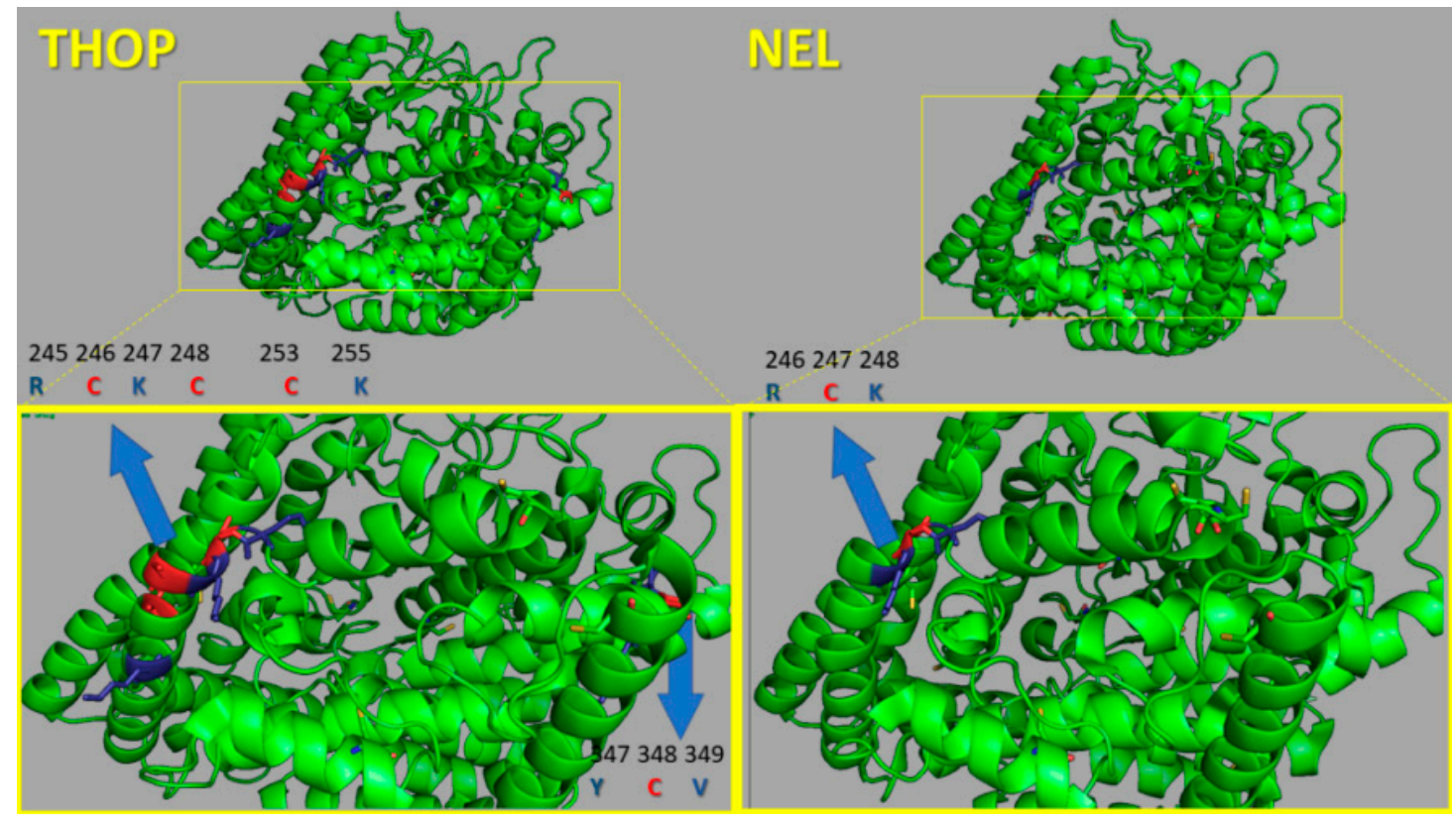

Figure 9. Comparative cartoon of Protein Databank (PDB) structure of THOP and NEL highlighting cysteine and basic amino acid residues of each enzyme. In THOP structure, there are three exposed acidic cysteine residues: C246, C248 and C253, whereas NEL has only one exposed acidic cysteine residue that is $\mathrm{C} 247$. In the cartoon structures, cysteines are highlighted in red while the neighbor basic amino acids $\mathrm{R}$ and $\mathrm{K}$ are highlighted in blue.

For the application of rTHOP- and rNEL-GNPs for catalysis and therapeutics it is fundamental that the enzymes adsorbed on the GNPs retains and preferentially improved the catalytic properties and activity. The activity of GNP-immobilized rTHOP and rNEL was compared with the respective soluble forms of the enzymes.

\subsection{Increased Stability-Activity of Immobilized rTHOP and rNEL in GNPS}

The temporal activity preservation of both free and immobilized proteases was compared. Free enzymes showed higher activity than the immobilized ones, but the stability of in solution rTHOP and rNEL at room temperature decreased until complete loss of activity in a few hours (Figure 10). However, gold nanoparticles-enzymes preparations of rTHOP-GNP and rNEL-GNP maintained their proteolytic activity even after $24 \mathrm{~h}$ (retaining $8.1 \%$ and $7.3 \%$ of their activity, respectively). We also tested the possibility that HEPES-based GNP (without protein) could also be capable of stabilizing THOP activity. As observed, it resulted in a retention of $22 \%$ of its activity at the time of $6 \mathrm{~h}$, indicating the presence of in solution free GNPs are capable of stabilizing THOP activity. The extension of stability, however, was not comparable to GNP-immobilized THOP, still active after $24 \mathrm{~h}$. 


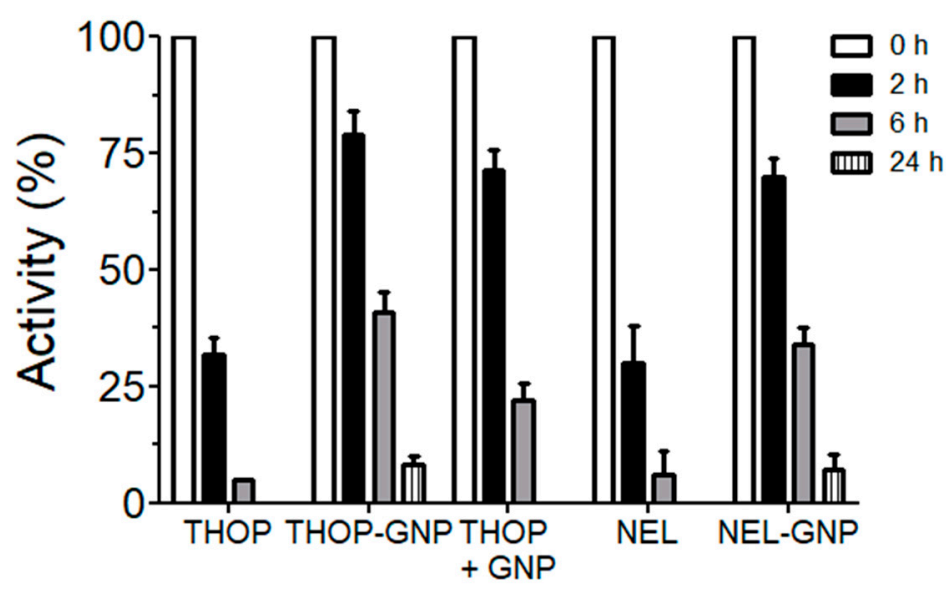

Figure 10. Increased activity based on stability of rTHOP-GNP and rNEL-GNP. Both THOP and NEL enzyme ultimately lose their activity after $6 \mathrm{~h}$ in solution at room temperature. When immobilized in the gold nanoparticles, the maintenance of activity is notable. GNP synthesized without any protease (HEPES-GNP) and incubated with in solution THOP was also capable of retaining THOP proteolytic activity. Samples were prepared and data obtained as described in the Material and Methods section.

Recently, there has been a growing interest in protein-driven nanoparticles synthesis for a variety of applications due to their unique properties of controllable morphology and size dispersion $[55,56]$. Proteins and amino acids are considered safe, non-toxic compounds and the production of gold nanoparticles GNPs using these materials are categorized as green and biocompatible materials and techniques. These systems can be used both for newly nanoparticle synthesis as well as immobilization techniques in order to increase protein stability and conduct functional studies. Enzymes are relevant and useful targets for selective cancer drugs and imaging probe delivery due to their substrate specificity the as well as the ability to perform biological catalysis. A wide variety of enzyme classes are overexpressed in tumors and other pathological microenvironments acting as potential targets for therapy and imaging studies [57-60]. Responsive drugs involving proteases can be designed for a target to increase selectivity and efficacy in a specific physiological process. In the case of the mammalian oligopeptidases THOP and NEL, their ability to regulate bioactive peptides, as the processing of the proand anti-angiogenic derived peptides angiotensin and bradykinin, may be used in relevant approaches in order to better comprehend these systems and their biology. A significant limitation to study THOP and NEL functions resides in their low stability in biological systems, which makes it challenging to study their physiology and biotechnological uses. One possibility to surpass these problems is to immobilize these enzymes in order to conduct these studies. Here we defined conditions capable of generating stable nanometric gold nanoparticle immobilized to both THOP and NEL proteases; and, importantly, retaining their proteolytic activity. The observed positive effects of immobilization in the proteolytic activity of THOP and NEL may be in part due to the impossibility to generate high molecular weight inactive forms, whose reversibility depends on specific cysteine residues that compose the disulfide. In addition, and noteworthy, the retention of activity indicates a gain of stability in the structure-function of both THOP and NEL, showing that immobilization on gold nanoparticles can be used as a valuable approach to different applications of both enzymes, from functional studies to therapeutic uses.

\section{Material and Methods}

\subsection{Chemicals}

Culture medium supplies were purchased from Thermo Fisher DTT (dithiothreitol), HEPES, Tris, $\mathrm{NaCl}$, IPTG (Isopropyl- $\beta$-D-thiogalactoside), sodium borohydride and metallic gold salt (tetrachloro auric acid trihydrate-HAuCl${ }_{4}$ ) were purchased from Sigma-Aldrich Chemical Co. (St. Louis, MO, USA). 


\subsection{Enzyme Production}

THOP and NEL expression and purification were conducted as already described with few adaptations $[47,61]$. Briefly, the liquid culture of E. coli BL21-DE3 containing the pET28a (+) constructs for expression of wild type thimet oligopeptidase and neurolysin (rTHOP and rNEL) and THOP mutant $6 \mathrm{M}$ were induced by IPTG. Sonicated soluble extracts of bacteria culture were filtered and purified using affinity-based HisTrap FF column (GE) in an AKta system (GE) and eluted in a $50 \mathrm{mM}$ Tris-buffer $100 \mathrm{mM} \mathrm{NaCl} \mathrm{pH} 7.4$ using increasing concentrations of imidazole. Purity was followed by SDS-PAGE. The specific activity of both proteases was measured using the fluorogenic substrate Abz-GFSPFRQ-EDDnp, in a $50 \mathrm{mM}$ Tris, $100 \mathrm{mM} \mathrm{NaCl}$ buffer ( $\mathrm{pH} 7.4$ ) at $37^{\circ} \mathrm{C}$ using the specific inhibitor JA2 for THOP [22]. Fluorescent products were followed at the excitation wavelength of $420 \mathrm{~nm}$ and an emission wavelength of $320 \mathrm{~nm}$ in a spectrofluorimeter Hitachi F7000 (Tokyo, Japan). After $5 \mathrm{~min}$ pre-incubation, enzymes $(0.1 \mathrm{nM})$ were added to the assay buffer with or without DTT $(1 \mathrm{mM})$, and the fluorescence kinetic recorded for $10 \mathrm{~min}$. The concentration of the substrate was determined colorimetrically by absorbance of the 2, 4-dinitrophenyl group $\left(\varepsilon_{365}=17,300 \mathrm{M}^{-1} . \mathrm{cm}^{-1}\right)$. Enzyme concentration for initial rate determination was chosen for hydrolyzing less than $5 \%$ of the substrate present. All the obtained data were fitted by nonlinear least-squares equations, using GRAFIT v.5.03 software [62].

\subsection{Gold Nanoparticle Synthesis}

All syntheses were performed in a laminar flow cabinet using small lab glass vials clear with a black screw cap. The glassware for synthesis was previously cleaned to avoid undesired nucleation aggregation of colloidal gold solutions [56]. The addition of reagents was performed as follows: Milli-Q deionized water, $0.2 \mathrm{mM}$ sodium phosphate buffer plus HEPES, pH 9.0, $100 \mu \mathrm{L}$ of protein solution per $\mathrm{mL}$ and tetrachloroauric acid solution $(400 \mu \mathrm{M})$. GNPs were synthesized at $40{ }^{\circ} \mathrm{C}$ for $2 \mathrm{~h}$ on a vat dry bath and let stabilize at room temperature. After $24 \mathrm{~h}$ of synthesis, the GNP colloidal suspensions were centrifuged and resuspended in $0.2 \mathrm{mM}$ sodium phosphate buffer plus HEPES, $\mathrm{pH} 7.0$ and stored at $4{ }^{\circ} \mathrm{C}$. Several syntheses were performed and characterized by UV-vis to guarantee reproducibility. GNPs synthesized with sodium borohydride (GNP-BH) were prepared by a reaction between sodium borohydride $(2 \mathrm{mM})$ in water and tetrachloroauric acid solution $(0.25 \mathrm{mM})$ at $0{ }^{\circ} \mathrm{C}$ and maintained under agitation $\left(200 \mathrm{rpm}\right.$ ) for $15 \mathrm{~min}[63,64]$. This solution was maintained for $24 \mathrm{~h}$ at $4{ }^{\circ} \mathrm{C}$, and enzymes were added and incubated for $4 \mathrm{~h}$ before UV-vis, dynamic light scattering (DLS) and Zeta potential measurements [65].

\subsection{Zeta Potential and DLS Measurements}

The Zeta potential $(\zeta)$ of GNPs were all measured at $25^{\circ} \mathrm{C}$ using a Zetasizer NanoZS (Malvern instruments Ltd., Worcestershire, UK). All GNPs solution was diluted in Milli-Q deionized water by $50 \%$ immediately before measurement. Three repeats for each sample were conducted to estimate the error in the measurements. Each measurement was taken by conducting 30 runs [66]. DLS (dynamic light scattering) measurements were acquired using the same instrument operating in the backward (a scattering angle of $173^{\circ}$ ) [67].

\subsection{UV-vis Spectra}

This spectroscopy was used to quantify proteins and characterize nanoparticles. UV-vis also characterized the optical properties of metallic nanoparticles, including absorbed radiation $\left(\sigma_{\mathrm{abs}}\right)$ and scattered radiation $\left(\sigma_{\mathrm{sca}}\right)$, where $\sigma_{\text {total }}=\sigma_{\mathrm{abs}}+\sigma_{\mathrm{sca}}$. Samples were analyzed in quartz cuvettes with optical path 1.0 or $0.5 \mathrm{~cm}$. A UV-visible Photodiode Array Spectrophotometer MultiSpec-1501 spectrophotometer (Shimadzu Co, Kyoto, Japan) was used. The synthesis temperature of the GNPs was controlled by a thermal bath coupled to the spectrophotometer. 


\subsection{Circular Dichroism}

The CD measurements were carried out in a J-815 Circular Dichroism Spectrometer equipped with Peltier single cell holder (Jasco International Co Ltd., Tokyo, Japan) using quartz cuvettes with a 1.0 or 0.5 optical path; bandwidth, $1.0 \mathrm{~nm}$; scanning speed, $50 \mathrm{~nm} / \mathrm{min}$ and four accumulations.

\subsection{Atomic Force Microscopy}

Samples were prepared by spreading the protein-GNP solution onto a freshly cleaved mica substrate and solvent dried using a nitrogen stream. AFM in the intermittent contact mode was performed using a scanning probe microscope equipped with a controller instruments and tip in an AFM XE7 Park System, Korea, using adjustable resonance frequency.

\section{Conclusions}

In the present study, it was reported the synthesis of gold nanoparticles in situ using HEPES as reducing agent assisted by the presence of the recombinant proteolytic enzymes THOP and NEL that remained immobilized on the gold nanoparticles based on the following evidences: (i) The presence of significant spectral differences observed in the UV region that is consistent with different organic ligands on the GNP surfaces; (ii) proteolytic activity of GNPs produced using HEPES and assisted by THOP and NEL that is absent in GNPs produced exclusively by HEPES and (iii) significant gain of structural and catalytic stability of rTHOP and rNEL associated with GNP relative to the free enzymes. Free enzymes lost $70 \%$ and $95 \%$ after 2 and $6 \mathrm{~h}$, respectively whereas the dropping of activity decreased to $30 \%$ and $60 \%$ after the same times of aging. Important to note that THOP gained stability even when it was added to gold nanoparticles previously fabricated with HEPES that was consistent with a binding capacity on gold nanoparticles; (iv) the significant gain of colloidal stability exhibited by gold nanoparticles produced with HEPES assisted by the enzymes and (v) in addition, the binding capacity of THOP on gold nanoparticles was also corroborated in bare GNPs synthesized with sodium borohydride that was evidenced by UV-visible spectroscopy and zeta potential.

Supplementary Materials: The following are available online at http://www.mdpi.com/2073-4344/10/1/78/s1, Figure S1: UV-vis spectra of bare GNPs synthesized using sodium borohydride, Figure S2: Characterization of GNPs synthesized using NaBH4, Table S1: Zeta potential and $\mathrm{pH}$ values.

Author Contributions: Conceptualization, A.M.M.B., I.L.N.-C., M.Y.I. and V.O.; methodology, A.M.M.B., I.L.N.-C., M.Y.I. and V.O.; formal analysis, A.M.M.B., I.L.N.-C., M.Y.I., V.O.; investigation, A.M.M.B., M.P.C.R., M.Y.I.; writing-original draft preparation, M.Y.I. and I.L.N.-C.; writing-review and editing, M.Y.I., V.O. and I.L.N.-C.; supervision, M.Y.I. and I.L.N.-C.; project administration, M.Y.I. and I.L.N.-C.; funding acquisition, M.Y.I, V.O. and I.L.N.-C. All authors have read and agreed to the published version of the manuscript.

Funding: This research was funded by Fundação de Amparo à Pesquisa do Estado de São Paulo, grants 2017/02317-3, 2018/09158-0 and 2019/01487-7 and by Conselho Nacional de Desenvolvimento Científico e Tecnológico, grant numbers 30924/2017-9 and 309247/2017-9. FAPESP 2015/017688-0, 2017/02317-2, SisNano (402289/2013-7), NBB/UFABC, CAPES grant 001, CEM/UFABC for access to facilities.

Acknowledgments: We are grateful to the funding agencies FAPESP, CNPq, and CAPES. Paulo Costa and Nova Analítica are kindly acknowledged for lending the Park XE7 AFM instrument used in this work to the Structural Biophysics Laboratory (Emerson R. Silva). We also thank Emerson Silva and Lucas Mello for the valuable discussion concerning the AFM data and David da Mata Lopes for technical assistance.

Conflicts of Interest: The authors declare no conflict of interest.

\section{References}

1. Emerich, D.F.; Thanos, C.G. The pinpoint promise of nanoparticle-based drug delivery and molecular diagnosis. Biomol. Eng. 2006, 23, 171-184. [CrossRef]

2. Couto, C.; Vitorino, R.; Daniel-da-Silva, A.L. Gold nanoparticles and bioconjugation: A pathway for proteomic applications. Crit. Rev. Biotechnol. 2017, 37, 238-250. [CrossRef] [PubMed]

3. Dhar, S.; Maheswara Reddy, E.; Shiras, A.; Pokharkar, V.; Prasad, B.L.V. Natural gum reduced/stabilized gold nanoparticles for drug delivery formulations. Chem.-A Eur. J. 2008, 14, 10244-10250. [CrossRef] [PubMed] 
4. Selvaraj, V.; Alagar, M. Analytical detection and biological assay of antileukemic drug 5-fluorouracil using gold nanoparticles as probe. Int. J. Pharm. 2007, 337, 275-281. [CrossRef] [PubMed]

5. Rastogi, L.; Kora, A.J.; Arunachalam, J. Highly stable, protein capped gold nanoparticles as effective drug delivery vehicles for amino-glycosidic antibiotics. Mater. Sci. Eng. C 2012, 32, 1571-1577. [CrossRef] [PubMed]

6. Mitra, P.; Chakraborty, P.K.; Saha, P.; Ray, P.; Basu, S. Antibacterial efficacy of acridine derivatives conjugated with gold nanoparticles. Int. J. Pharm. 2014, 473, 636-643. [CrossRef]

7. Miranda, É.G.A.; Tofanello, A.; Brito, A.M.M.; Lopes, D.M.; Albuquerque, L.J.C.; de Castro, C.E.; Costa, F.N.; Giacomelli, F.C.; Ferreira, F.F.; Araújo-Chaves, J.C.; et al. Effects of Gold Salt Speciation and Structure of Human and Bovine Serum Albumins on the Synthesis and Stability of Gold Nanostructures. Front. Chem. 2016, 4, 13. [CrossRef]

8. Tofanello, A.; Miranda, É.G.A.; Dias, I.W.R.; Lanfredi, A.J.C.; Arantes, J.T.; Juliano, M.A.; Nantes, I.L. PH-Dependent Synthesis of Anisotropic Gold Nanostructures by Bioinspired Cysteine-Containing Peptides. ACS Omega 2016, 1, 424-434. [CrossRef]

9. Brito, A.M.M.; Belleti, E.; Menezes, L.R.; Lanfredi, A.J.C.; Nantes-Cardoso, I.L. Proteins and Peptides at the Interfaces of Nanostructures. Ann. Braz. Acad. Sci. 2019, 91, 1-17, in press. [CrossRef]

10. Melo, A.F.A.A.; Luz, R.A.S.; Iost, R.M.; Nantes, I.L.; Crespilho, F.N. Highly Stable Magnetite Modified with Chitosan, Ferrocene and Enzyme for Application in Magneto-Switchable Bioelectrocatalysis. J. Braz. Chem. Soc. 2013, 24, 285-294. [CrossRef]

11. Pereira, A.R.; Iost, R.M.; Martins, M.V.A.; Yokomizo, C.H.; da Silva, W.C.; Nantes, I.L.; Crespilho, F.N. Molecular interactions and structure of a supramolecular arrangement of glucose oxidase and palladium nanoparticles. Phys. Chem. Chem. Phys. 2011, 13, 12155-12162. [CrossRef] [PubMed]

12. Araújo, J.N.; Tofanello, A.; da Silva, V.M.; Sato, J.A.P.; Squina, F.M.; Nantes, I.L.; Garcia, W. Photobiosynthesis of stable and functional silver/silver chloride nanoparticles with hydrolytic activity using hyperthermophilic $\beta$-glucosidases with industrial potential. Int. J. Biol. Macromol. 2017, 102, 84-91. [CrossRef] [PubMed]

13. Cruz, G.F.; Tofanello, A.; Araújo, J.N.; Nantes-Cardoso, I.L.; Ferreira, F.F.; Garcia, W. Fast One-Pot Photosynthesis of Plasmonic Protein-Coated Silver/Silver Bromide Nanoparticles with Efficient Photocatalytic Performance. J. Inorg. Organomet. Polym. Mater. 2018, 28, 2056-2062. [CrossRef]

14. Dauch, P.; Vincent, J.P.; Checler, F. Molecular cloning and expression of rat brain endopeptidase 3.4.24.16. J. Biol. Chem. 1995, 270, 27266-27271. [CrossRef] [PubMed]

15. Shrimpton, C.N.; Smith, A.I.; Lew, R.A. Soluble metalloendopeptidases and neuroendocrine signaling. Endocr. Rev. 2002, 23, 647-664. [CrossRef]

16. Moreau, M.; Westlake, T.; Zampogna, G.; Popescu, G.; Tian, M.; Noutsos, C.; Popescu, S. The Arabidopsis oligopeptidases TOP1 and TOP2 are salicylic acid targets that modulate SA-mediated signaling and the immune response. Plant J. 2013, 76, 603-614. [CrossRef]

17. Castro, L.M.; Cavalcanti, D.M.L.P.; Araujo, C.B.; Rioli, V.; Icimoto, M.Y.; Gozzo, F.C.; Juliano, M.; Juliano, L.; Oliveira, V.; Ferro, E.S. Peptidomic analysis of the neurolysin-knockout mouse brain. J. Proteom. 2014, 111, 238-248. [CrossRef]

18. Kim, S.I.; Grum-Tokars, V.; Swanson, T.A.; Cotter, E.J.; Cahill, P.A.; Roberts, J.L.; Cummins, P.M.; Glucksman, M.J. Novel roles of neuropeptide processing enzymes: EC3.4.24.15 in the neurome. J. Neurosci. Res. 2003, 74, 456-467. [CrossRef]

19. Dahms, P.; Mentlein, R. Purification of the main somatostatin-degrading proteases from rat and pig brains, their action on other neuropeptides, and their identification as endopeptidases 24.15 and 24.16. Eur. J. Biochem. 1992, 208, 145-154. [CrossRef]

20. Dos Santos, N.B.; Franco, R.D.; Camarini, R.; Munhoz, C.D.; Eichler, R.A.; Gewehr, M.C.; Reckziegel, P.; Llanos, R.P.; Dale, C.S.; Borges, V.F. Thimet Oligopeptidase (EC 3.4.24.15) Key Functions Suggested by Knockout Mice Phenotype Characterization. Biomolecules 2019, 9, 382. [CrossRef]

21. Checler, F.; Ferro, E.S. Neurolysin: From Initial Detection to Latest Advances. Neurochem. Res. 2018, 43, 2017-2024. [CrossRef] [PubMed]

22. Smith, A.I.; Lew, R.A.; Shrimpton, C.N.; Evans, R.G.; Abbenante, G. A novel stable inhibitor of endopeptidases EC 3.4.24.15 and 3.4.24.16 Potentiates bradykinin-induced hypotension. Hypertension 2000, 35, 626-630. [CrossRef] [PubMed] 
23. Checler, F.; Barelli, H.; Kitabgi, P.; Vincent, J.P. Neurotensin metabolism in various tissues of central and peripheral origins: Ubiquitous involvement of a novel neurotensin degrading metalloendopeptidase. Biochimie 1988, 70, 75-82. [CrossRef]

24. Hernandez, M.E.; Rembao, J.D.; Hernandez-Baltazar, D.; Castillo-Rodriguez, R.A.; Tellez-Lopez, V.M.; Flores-Martinez, Y.M.; Orozco-Barrios, C.E.; Rubio, H.A.; Sánchez-García, A.; Ayala-Davila, J.; et al. Safety of the intravenous administration of neurotensin-polyplex nanoparticles in BALB/c mice. Nanomed. Nanotechnol. Biol. Med. 2014, 10, 745-754. [CrossRef]

25. Chabry, J.; Checler, F.; Vincent, J.P.; Mazella, J. Colocalization of neurotensin receptors and of the neurotensin-degrading enzyme endopeptidase 24-16 in primary cultures of neurons. J. Neurosci. 1990, 10, 3916-3921. [CrossRef]

26. Checler, F.; Vincent, J.P.; Kitabgi, P. Inactivation of Neurotensin by Rat Brain Synaptic Membranes Partly Occurs Through Cleavage at the Arg8-Arg9 Peptide Bond by a Metalloendopeptidase. J. Neurochem. 1985, 45, 1509-1513. [CrossRef]

27. Barelli, H.; Fox-Threlkeld, J.E.T.; Dive, V.; Daniel, E.E.; Vincent, J.P.; Checler, F. Role of endopeptidase 3.4.24.16 in the catabolism of neurotensin, in vivo, in the vascularly perfused dog ileum. Br. J. Pharmacol. 1994, 112, 127-132. [CrossRef]

28. Vincent, B.; Jiracek, J.; Noble, F.; Loog, M.; Roques, B.; Dive, V.; Vincent, J.P.; Checler, F. Effect of a novel selective and potent phosphinic peptide inhibitor of endopeptidase 3.4.24.16 on neurotensin-induced analgesia and neuronal inactivation. Br. J. Pharmacol. 1997, 121, 705-710. [CrossRef]

29. Genden, E.M.; Molineaux, C.J. Inhibition of endopeptidase-24.15 decreases blood pressure in normotensive rats. Hypertension 1991, 18, 360-365. [CrossRef]

30. Shrimpton, C.N.; Abbenante, G.; Lew, R.A.; Smith, A.I. Development and characterization of novel potent and stable inhibitors of endopeptidase EC 3.4.24.15. Biochem. J. 2000, 345, 351-356. [CrossRef]

31. Orlowski, M.; Michaud, C.; Chu, T.G. A soluble metalloendopeptidase from rat brain: Purification of the enzyme and determination of specificity with synthetic and natural peptides. Eur. J. Biochem. 1983, 135, 81-88. [CrossRef] [PubMed]

32. Orlowski, M.; Reznik, S.; Ayala, J.; Pierotti, A.R. Endopeptidase 24.15 from rat testes. Isolation of the enzyme and its specificity toward synthetic and natural peptides, including enkephalin-containing peptides. Biochem. J. 1989, 261, 951-958. [CrossRef] [PubMed]

33. Molina, H.M.; Carmona, A.K.; Kouyoumdjian, M.; Borges, D.R. Thimet oligopeptidase EC 3.4.24.15 is a major liver kininase. Life Sci. 2000, 67, 509-520. [CrossRef]

34. Ura, N.; Carretero, O.A.; Erdos, E.G. Role of renal endopeptidase 24.11 in kinin metabolism in vitro and in vivo. Kidney Int. 1987, 32, 507-513. [CrossRef] [PubMed]

35. Oliveira, V.; Ferro, E.S.; Gomes, M.D.; Oshiro, M.E.M.; Almeida, P.C.; Juliano, M.A.; Juliano, L. Characterization of thiol-, aspartyl-, and thiol-metallo-peptidase activities in Madin-Darby canine kidney cells. J. Cell. Biochem. 2000, 76, 478-488. [CrossRef]

36. Yang, X.P.; Saitoh, S.; Guillermo Scicli, A.; Mascha, E.; Orlowski, M.; Carretero, O.A. Effects of a metalloendopeptidase-24.15 inhibitor on renal hemodynamics and function in rats. Hypertension 1994, 23, I-235-I-239. [CrossRef]

37. Chu, T.G.; Orlowski, M. Soluble metalloendopeptidase from rat brain: Action on enkephalin-containing peptides and other bioactive peptides. Endocrinology 1985, 116, 1418-1425. [CrossRef]

38. Yamada, K.; Iyer, S.N.; Chappell, M.C.; Ganten, D.; Ferrario, C.M. Converting enzyme determines plasma clearance of angiotensin-(1-7). Hypertension 1998, 32, 496-502. [CrossRef]

39. Chappell, M.C.; Tallant, E.A.; Brosnihan, K.B.; Ferrario, C.M. Conversion of angiotensin i to angiotensin-(1-7) by thimet oligopeptidase (EC 3.4.24.15) in vascular smooth muscle cells. J. Vasc. Med. Biol. 1994, 5, 129-137.

40. Chappell, M.C.; Gomez, M.N.; Pirro, N.T.; Ferrario, C.M. Release of angiotensin-(1-7) from the rat hindlimb: Influence of angiotensin-converting enzyme inhibition. Hypertension 2000, 35, 348-352. [CrossRef]

41. Vincent, J.P.; Mazella, J.; Kitabgi, P. Neurotensin and neurotensin receptors. Trends Pharmacol. Sci. 1999, 20, 302-309. [CrossRef]

42. Devader, C.; Moreno, S.; Roulot, M.; Deval, E.; Dix, T.; Morales, C.R.; Mazella, J. Increased brain neurotensin and NTSR2 lead to weak nociception in NTSR3/sortilin knockout mice. Front. Neurosci. 2016, 10, 542. [CrossRef] [PubMed] 
43. Rashid, M.; Wangler, N.J.; Yang, L.; Shah, K.; Arumugam, T.V.; Abbruscato, T.J.; Karamyan, V.T. Functional up-regulation of endopeptidase neurolysin during post-acute and early recovery phases of experimental stroke in mouse brain. J. Neurochem. 2014, 129, 179-189. [CrossRef] [PubMed]

44. Jayaraman, S.; Al Shoyaib, A.; Kocot, J.; Villalba, H.; Alamri, F.F.; Rashid, M.; Wangler, N.J.; Chowdhury, E.A.; German, N.; Arumugam, T.V.; et al. Peptidase neurolysin functions to preserve the brain after ischemic stroke in male mice. J. Neurochem. 2019. Published electronically September 5. [CrossRef]

45. Wangler, N.J.; Jayaraman, S.; Zhu, R.; Mechref, Y.; Abbruscato, T.J.; Bickel, U.; Karamyan, V.T. Preparation and preliminary characterization of recombinant neurolysin for in vivo studies. J. Biotechnol. 2016, 234, 105-115. [CrossRef]

46. Pessoto, F.S.; Faria, P.A.; Cunha, R.L.O.R.; Comasseto, J.V.; Rodrigues, T.; Nantes, I.L. Organotellurane-promoted mitochondrial permeability transition concomitant with membrane lipid protection against oxidation. Chem. Res. Toxicol. 2007, 20, 1453-1461. [CrossRef]

47. Icimoto, M.Y.; Ferreira, J.C.; Yokomizo, C.H.; Bim, L.V.; Marem, A.; Gilio, J.M.; Oliveira, V.; Nantes, I.L. Redox modulation of thimet oligopeptidase activity by hydrogen peroxide. FEBS Open Bio 2017, 7, 1037-1050. [CrossRef]

48. Nantes, I.L.; Rodrigues, T.; Caires, A.C.F.; Cunha, R.L.O.R.; Pessoto, F.S.; Yokomizo, C.H.; Araujo-Chaves, J.C.; Faria, P.A.; Santana, D.P.; dos Santos, C.G. Specific effects of reactive thiol drugs on mitochondrial bioenergetics. J. Bioenerg. Biomembr. 2011, 43, 11-18. [CrossRef]

49. Rioli, V.; Gozzo, F.C.; Heimann, A.S.; Linardi, A.; Krieger, J.E.; Shida, C.S.; Almeida, P.C.; Hyslop, S.; Eberlin, M.N.; Ferro, E.S. Novel natural peptide substrates for endopeptidase 24.15, neurolysin, and angiotensin-converting enzyme. J. Biol. Chem. 2003, 278, 8547-8555. [CrossRef]

50. Malvezzi, A.; Higa, P.M.; Amaral, A.T.D.; Silva, G.M.; Gozzo, F.C.; Ferro, E.S.; Castro, L.M.; de Rezende, L.; Monteiro, G.; Demasi, M. The cysteine-rich protein Thimet oligopeptidase as a model of the structural requirements for S-glutathiolation and oxidative oligomerization. PLoS ONE 2012, 7, e39408. [CrossRef]

51. Demasi, M.; Piassa Filho, G.M.; Castro, L.M.; Ferreira, J.C.; Rioli, V.; Ferro, E.S. Oligomerization of the cysteinyl-rich oligopeptidase EP24.15 is triggered by S-glutathionylation. Free Radic. Biol. Med. 2008, 44, 1180-1190. [CrossRef] [PubMed]

52. Haiss, W.; Thanh, N.T.K.; Aveyard, J.; Fernig, D.G. Determination of Size and Concentration of Gold Nanoparticles from UV-Vis Spectra Determination of Size and Concentration of Gold Nanoparticles from UV - Vis Spectra. Anal. Chem. 2015, 79, 4215-4221. [CrossRef] [PubMed]

53. Lewis, D.J.; Day, T.M.; MacPherson, J.V.; Pikramenou, Z. Luminescent nanobeads: Attachment of surface reactive Eu(III) complexes to gold nanoparticles. Chem. Commun. 2006, 13, 1433-1435. [CrossRef] [PubMed]

54. Lewis, D.J.; Pikramenou, Z. Lanthanide-coated gold nanoparticles for biomedical applications. Coord. Chem. Rev. 2014, 273, 213-225. [CrossRef]

55. Yang, C.; Bromma, K.; Di Ciano-Oliveira, C.; Zafarana, G.; van Prooijen, M.; Chithrani, D.B. Gold nanoparticle mediated combined cancer therapy. Cancer Nanotechnol. 2018, 9, 4. [CrossRef]

56. Suchomel, P.; Kvitek, L.; Prucek, R.; Panacek, A.; Halder, A.; Vajda, S.; Zboril, R. Simple size-controlled synthesis of Au nanoparticles and their size-dependent catalytic activity. Sci. Rep. 2018, 8, 4589. [CrossRef]

57. Garrido, P.A.G.; Vandenbulcke, F.; Ramjaun, A.R.; Vincent, B.; Checler, F.; Ferro, E.; Beaudet, A. Confocal microscopy reveals thimet oligopeptidase (EC 3.4.24.15) and neurolysin (EC 3.4.24.16) in the classical secretory pathway. DNA Cell Biol. 1999, 18, 323-331. [CrossRef]

58. Olson, O.C.; Joyce, J.A. Cysteine cathepsin proteases: Regulators of cancer progression and therapeutic response. Nat. Rev. Cancer 2015, 15, 712-729. [CrossRef]

59. López-Otín, C.; Hunter, T. The regulatory crosstalk between kinases and proteases in cancer. Nat. Rev. Cancer 2010, 10, 278-292. [CrossRef]

60. López-Otín, C.; Matrisian, L.M. Emerging roles of proteases in tumour suppression. Nat. Rev. Cancer 2007, 7, 800-808. [CrossRef]

61. Oliveira, V.; Campos, M.; Melo, R.L.; Ferro, E.S.; Camargo, A.C.M.; Juliano, M.A.; Juliano, L. Substrate specificity characterization of recombinant metallo oligo-peptidases thimet oligopeptidase and neurolysin. Biochemistry 2001, 40, 4417-4425. [CrossRef] [PubMed]

62. Leatherbarrow, R.J. GraFit Version 5; Erithacus Software Ltd.: Horley, UK, 2011.

63. Brown, K.R.; Natan, M.J. Colloidal Gold: Principles, Methods, and Applications; Academic Press: San Diego, CA, USA, 1996. 
64. Polte, J.; Erler, R.; Thünemann, A.F.; Sokolov, S.; Ahner, T.T.; Rademann, K.; Emmerling, F.; Kraehnert, R. Nucleation and growth of gold nanoparticles studied via in situ small angle X-ray scattering at millisecond time resolution. ACS Nano 2010, 4, 1076-1082. [CrossRef] [PubMed]

65. Deraedt, C.; Salmon, L.; Gatard, S.; Ciganda, R.; Hernandez, R.; Ruiz, J.; Astruc, D. Sodium borohydride stabilizes very active gold nanoparticle catalysts. Chem. Commun. 2014, 50, 14194-14196. [CrossRef] [PubMed]

66. Wang, W.; Ding, X.; Xu, Q.; Wang, J.; Wang, L.; Lou, X. Zeta-potential data reliability of gold nanoparticle biomolecular conjugates and its application in sensitive quantification of surface absorbed protein. Colloids Surfaces B Biointerfaces 2016, 148, 541-548. [CrossRef]

67. Bhattacharjee, S. DLS and zeta potential-What they are and what they are not? J. Control. Release 2016, 235, 337-351. [CrossRef] [PubMed]

(C) 2020 by the authors. Licensee MDPI, Basel, Switzerland. This article is an open access article distributed under the terms and conditions of the Creative Commons Attribution (CC BY) license (http://creativecommons.org/licenses/by/4.0/). 